\author{
L.I. Nykyruy ${ }^{1}$, O.V. Yaremiichuk ${ }^{1,2}$, Z.R. Zapukhlyak ${ }^{1,2}$, R.S. Yavorskyi ${ }^{1,2}$, \\ P. Potera ${ }^{2}$, I.V. Malyarska ${ }^{1}$, O.Ya. Fedoryk ${ }^{1}$
}

\title{
Optical Properties of CdS/CdTe Heterojunction Prepared by Physical Vapor Deposition Technique
}

\author{
${ }^{1}$ Vasyl Stefanyk Precarpathian National University, T. Shevchenko, 57, 76-018, Ukraine, e-mail: roctyslaw@ gmail.com \\ ${ }^{2}$ Rzeszow University, Rejtana 16C, 35-959 Rzeszow, Poland
}

\begin{abstract}
The paper presents the study of the optical properties of a thin layer of Cadmium Sulphide deposited on Cadmium Telluride films. CdTe thin films were obtained by vapor phase condensation method using different technological factors, in particular, different thickness (different time of deposition $\tau$ ) on glass substrates. After deposition the optical properties were analysed by Swanepoel method, using transmission spectra. The upper thin layer of $\mathrm{CdS}$ was deposited by thermal evaporation method on CdTe thin films. The change in optical properties of CdS/CdTe heterojunction in comparison with CdTe thin films was investigated. Using a Swanepoel method were calculated the main optical constants, such as refractive index, absorption coefficient and optical conductivity. By this method the thickness of the thin film was determined and compared with the experimental values obtained by the profilometer.
\end{abstract}

Keywords: thin films heterojunction, thermal evaporation method, optical properties.

Article acted received 28.08.2018; accepted for publication 15.09.2018.

\section{Introduction}

Thin film PV solar cell has been considered one of the promising solar cells due to its high energy conversion efficiency, low cost and convenience for large scale production. The most successful thin film solar cells have been cadmium telluride (CdTe), copper indium gallium selenide (CIGS) and amorphous silicon (a-Si) with efficiencies of $18.3 \%, 20 \%$ and 12.3 , respectively [1]. Typically, the efficiencies of thin-film solar cells are lower compared with silicon (wafer-based) solar cells, but manufacturing costs are also lower. It was reported that [2], CdTe technology costs about 30\% less than CIGS technology and $40 \%$ less than $\mathrm{A}-\mathrm{Si}$ technology.

The theoretical efficiency of $\mathrm{CdS} / \mathrm{CdTe}$ solar cells is predicted to be up to $28-30 \%$ [3, 4]. However, the real efficiency of PV solar cells based on the n-CdS / p-CdTe heterojunction in a superstrate structure is currently $20.4 \%$ [5], and the efficiency of solar modules with an area $>1 \mathrm{~cm}^{2}$ is $16.5 \%[6,7]$ The major impact factors for this difference are due to the optical losses, surface recombination, recombination in the space-charge region and rear contact effect.

The best small-area CdTe thin-film cells manufactured show more than $15 \%$ conversion efficiency [8]. Large-area modules with aperture efficiencies in excess of $10 \%$ have also been demonstrated (Ullal et al., 2000). First Solar (the largest CdTe manufacturer) reported fleet average efficiencies increasing from $12.9 \%$ in 2012 to $16.6 \%$ in 2016 for their CdTe modules (First Solar, 2017). For CdTe cells, module efficiency record for the moment is $18.6 \%$. The best CIGS reported efficiencies so far were $17.5 \%$ for modules (Green et al., 2017). There is also significant industrial production based on $\mathrm{CdTe} / \mathrm{CdS}$ solutions, represented to a large extent by American corporation First Solar, which is a supplier of PV modules used in the currently largest Agua Caliente Solar Project solar power plant in Arizona [9]. It should be noted that thin film technology based on CdTe is the first technology that has allowed to low the production costs of solar energy up to $0.57 \$ / W$ [10]. In spite of the $10 \%$ difference in the lattice constants of $\mathrm{CdS}$ and $\mathrm{CdTe}$, they form an electrically excellent heterojunction, as shown by its high fill factors up to $\mathrm{FF}=0.75$ in the devices made.

Thin film flexible solar cells using $\mathrm{CdS} / \mathrm{CdTe}$ semiconductor compounds are currently in active research and in the field of interest of several research centers in the world. This is due to the fact that flexible PV cells have a record high power per unit weight - more than $2 \mathrm{~kW} / \mathrm{kg}$ [11]. Such characteristics are achieved thanks the construction of a flexible SC, where the glass substrate is replaced by a polyamide film. In recent years 
there have also been reports of the first attempts to manufacture this type of structures on elastic substrates, including both configurations: superstrate [12-13] and substrate [14].

At present, a lot of methods have been developed for the production of thin CdTe films. This paper presents the thermal evaporation method [15]. In order to calculate the refractive index from optical transmittance data the interference patterns in the transmittance spectra should be suppressed by generating the envelope around transmittance maxima and minima [16]. Than the interference pattern free transmittance spectra of deposited films should be used to calculate the refractive index using Swanepoel method [17].

This straightforward method proposed by Swanepoel [18], based on the use of the extremes of the interference fringes of transmission spectrum only, will be used in order to derive the real and imaginary parts of the complex index and also the thickness for the semiconductor film. Through the use of materials with a higher optical absorption coefficient, it is possible to reduce the thickness of active photovoltaic cell layers [19], which affects not only the decrease in production costs, but also the possible weight reduction of photovoltaic devices depending on the substrate used.

There are number of papers theoretically focused on detailed investigation of the dependence of the efficiency of $\mathrm{CdS} / \mathrm{CdTe}$ thin film solar cells on some properties [20 - 24]. However, the results of complex experimental studies of the spectral dependences of the main optical constants have been presented a little. Therefore, our studies are of great importance for the further development of highly efficient devices based on heterojunctions for electronics and solar energy.

\section{Experiment Methodology}

First the thin films of CdTe were deposited on a cleaned glass substrates by thermal evaporation method. In the used installation can be to receive series (5-15 films) in a single cycle for various technological factors: different thickness $d=(0.01-12) \mu \mathrm{m}$ at a constant temperature of deposition $\mathrm{T}_{\mathrm{S}}=(300-570) \mathrm{K}$; uniform thickness $d$ with different $T_{S}$; different temperature of evaporation $\mathrm{T}_{\mathrm{E}}(600-1070) \mathrm{K}$ with constant thickness $d$ or deposition temperature $T_{S}$.

Thin films of CdTe for research were obtained with different thicknesses (different deposition time $\tau$ ) at a constant $T_{S}$ and $T_{E}$ (Table 1). The growth temperature $T_{s}$ was $470 \mathrm{~K}$, the evaporation temperature of presynthesized compounds CdTe was $T_{E}=870 \mathrm{~K}$. The thicknesses of thin films were set by deposition time $\tau=$ (60 - 180) sec.

Further the next layer of CdS was deposited on CdTe thin films by thermal evaporation method. The technological parameters shows Table I.

The samples thickness was analysed using profilometer Bruker Dektak XT. Optical transmission spectra was investigated by measuring transmittance, $\mathrm{T}$ at normal incidence and room temperature. The measurements were carried out in the wavelength range of $190-3300 \mathrm{~nm}$ with $1 \mathrm{~nm}$ step using Agilent Technologies Cary Series UV-Vis-NIR
Spectrophotometer.

Table I

Technological parameters of CdTe and CdS/CdTe thin films

\begin{tabular}{|c|c|c|c|c|}
\hline $\begin{array}{c}\text { Samp- } \\
\text { le } \\
\text { num- } \\
\text { ber }\end{array}$ & $\begin{array}{c}\text { Substrate } \\
\text { tempera- } \\
\text { ture } \\
\mathrm{T}_{\mathrm{S}}, \mathrm{K}\end{array}$ & $\begin{array}{c}\text { Evapora- } \\
\text { tion } \\
\text { tempera- } \\
\text { ture } \\
\mathrm{T}_{\mathrm{E}}, \mathrm{K}\end{array}$ & $\begin{array}{c}\text { Depositi } \\
\text { on time } \\
\tau, \mathrm{sec}\end{array}$ & $\begin{array}{c}\text { Thick- } \\
\text { ness } \\
\mathrm{d}, \mathrm{nm}\end{array}$ \\
\hline \multicolumn{5}{|c|}{ CdTe/glass } \\
\hline 21 & 470 & 820 & 180 & 1485 \\
\hline 24 & 470 & 845 & 160 & 1215 \\
\hline 21 & 470 & 1150 & 45 & 1689 \\
\hline 24 & 470 & 1150 & 30 & 1490 \\
\hline
\end{tabular}

\section{Results and discussion}

Optical characterization of thin films gives information about other physical properties, e.g., bandgap energy, band structure, and optically active defects [25]. The effects of thickness and heterojunction properties on the optical transmittance of the CdTe and $\mathrm{CdS} / \mathrm{CdTe}$ films have been studied. The region of fundamental absorption was observed in transmission spectra. The transmission spectra of CdTe and CdS/CdTe thin films obtained on the glass substrates with different thicknesses were measured in the wavelength range from 180 to $3300 \mathrm{~nm}$ and are shown in Figures 1-2. It can be observed that the films are highly transparent in the near infrared region. Absorption edge is about $800 \mathrm{~nm}$ for all samples, which is completely consistent with the width of the bandgap of CdTe thin films [26]. In addition, the observed interference patterns in the optical transmission spectra are the indication for the thickness homogeneity of deposited films [27].

On Figs. 1-2 can be seen that for as grown CdTe films the transmission values reach up to $90 \%$, which also indicates the high transparency of the films. For a thick film CdTe No21 (Fig.1) is observed a smoother growth of the transmittance with a wavelength compared to the sample CdTe No24 (Fig. 2). Here is worth to note, that the number of "interference maxima" also depends on the thickness of the film. This could be explained by the fact that there is a difference between the refractive indexes of the film and substrate and also due to the interference of multiple light reflections Fig. 3 [28].

Transmission values for $\mathrm{CdS} / \mathrm{CdTe}$ heterojunction are slightly lower than those for pure CdTe films, which may indicate greater reflection or scattering in film thickness.

One of the most popular methods that uses these interference fringes to determine the optical properties of 


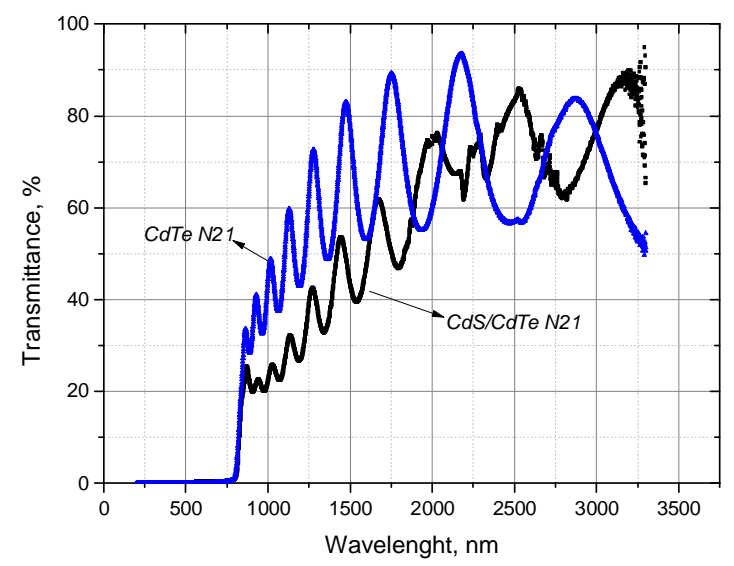

Fig. 1. Optical transmission spectra of CdTe thin film and $\mathrm{CdS} / \mathrm{CdTe}$ heterojunction (sample 21).

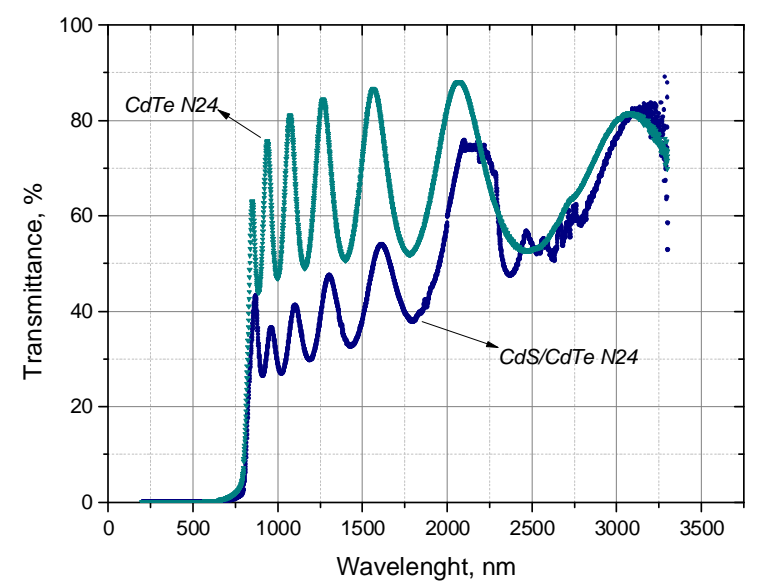

Fig. 2. Optical transmission spectra of CdTe thin film and $\mathrm{CdS} / \mathrm{CdTe}$ heterojunction (sample 24).

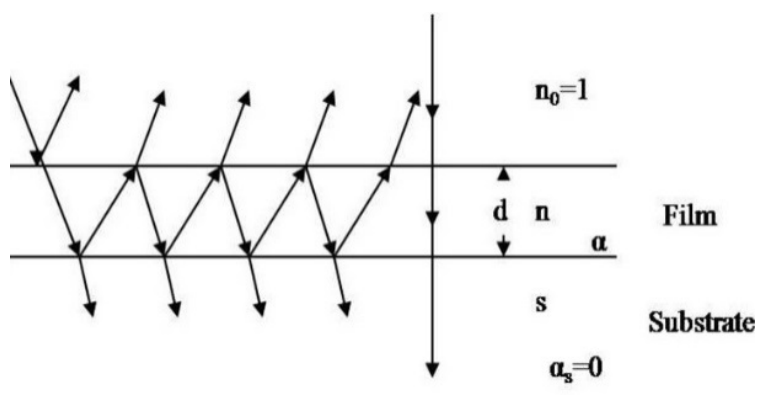

Fig. 3. Schematic diagram of a thin film on the substrate. Arrows indicate transmission and reflection at different interfaces.

the material is the Swanepoel method [29].

The shape of a thin film on a transparent substrate looks like on Fig. 3. In this figure, $\mathrm{n}, \alpha, \mathrm{d}$ and $\mathrm{T}$ denote the refractive index, absorption coefficient, thickness and transmission of the film, respectively. The transparent substrate has a thickness of several orders of magnitude larger with index of refractions and absorption coefficient $\alpha_{\mathrm{s}}=0$ and transmittance $\mathrm{T}_{\mathrm{s}}$. The index of refraction for air is $\mathrm{n}_{0}=1$. If the thickness $\mathrm{d}$ is uniform then the interference effects generate a spectrum. The interference fringes can be used to calculate the optical constants of the film such as refractive index, film thickness, absorption coefficient and optical conductivity.

The transmission $\mathrm{T}$ for the normal incidence resulted from the interference of the wave transmitted from three interfaces can be calculated as [30]:

$$
T=T(n, x)=\frac{A x}{B-C x \cos (\varphi)+D x^{2}}
$$

where:

$$
\begin{aligned}
& A=16 n^{2} s \\
& B=(n+1)^{2}\left(n+s^{2}\right) \\
& C=2\left(n^{2}-1\right)\left(n^{2}-s^{2}\right) \\
& D=(n-1)^{2}\left(n-s^{2}\right) \\
& \varphi=\frac{4 \pi n d}{\lambda} \\
& x=e^{-\alpha d}
\end{aligned}
$$

Maximum and minimum of interference fringes are determined from the following equations:

$$
\begin{aligned}
T_{M} & =\frac{A x}{B-C x+D x^{2}} \\
T_{m} & =\frac{A x}{B+C x+D x^{2}}
\end{aligned}
$$

The refractive index of the substrate is found from the following expression $\left(\mathrm{T}_{\mathrm{s}}=\max \right)$ :

$$
s=\frac{1}{T_{s}}+\left(\frac{1}{T_{s}^{2}}-1\right)^{\frac{1}{2}}
$$

From the equations above the refractive index is determined:

where

$$
n=\left(N+\left(N^{2}-s^{2}\right)^{1 / 2}\right)^{1 / 2}
$$

$$
N=\frac{2\left(T_{M}-T_{m}\right)}{T_{M} T_{m}}+\frac{z^{2}+1}{2}
$$

Using the equations (11) and (12) and taking into account $\mathrm{s}=0.92$ the refractive index of samples CdTe and CdS/CdTe can be obtained. The calculated values of refractive index (n) are presented in Tables II-V for CdTe thin films and heterojunction of $\mathrm{CdS} / \mathrm{CdTe}$. The refractive index is the range of frequencies in which films are weakly absorbing. Figures 4-5 shows the variation of refractive index of CdTe films and the average value is about 2.48 for a sample No 21 and 2.45 for a sample No 24. This values are completely consistent with the literary ones that matter for CdTe thin films to 2.5 [31]. For heterojunction of CdS/CdTe these values are about 2.52 for a sample No21 and 2.72 for No 24. These values is consistent with literary [32].

The thickness of the film is calculated from the equation:

$$
d=\frac{\lambda_{1} \lambda_{2}}{2\left(\lambda_{1} n_{2}-\lambda_{2} n_{1}\right)}
$$

provided that $n_{1}$ and $n_{2}$ are the refractive indices of the wave's $\lambda_{1}$ and $\lambda_{2}$ calculated for two neighboring maxima or minima. For the samples CdS/CdTe No 21 and CdTe No 21, the thicknesses of the films are presented in Table II and Table III, respectively, as $\mathrm{d}_{1}$.

Comparing the experimental and calculated values of the thickness, can be note that a small difference in value is associated with the error in experimental studies.

The order of interference $m$ at the maxima of transmission spectra for wavelength $\lambda_{1}$ is: 
L.I. Nykyruy, O.V. Yaremiichuk, Z.R. Zapukhlyak, R.S. Yavorskyi, P. Potera, I.V. Malyarska, O.Ya. Fedoryk

Table II

Calculated optical properties by Swanepoel method for CdS/CdTe heterojunction (sample 21)

\begin{tabular}{|c|c|c|c|c|c|c|c|}
\hline$\lambda, \mathbf{n m}$ & $\mathbf{T}_{\mathbf{M}}$ & $\mathbf{T}_{\mathrm{m}}$ & $\mathbf{n}$ & $\mathbf{d}_{1}, \mathbf{n m}$ & $\mathbf{m}$ & $\alpha, \mathbf{c m}^{-1}$ & $\sigma_{\text {opt }}, 10^{11}$ \\
\hline 2000 & 0.7562 & 0.5164 & 2.237 & & & & \\
\hline 1790 & 0.6739 & 0.4688 & 2.275 & & & & \\
\hline 1672 & 0.6184 & 0.4275 & 2.353 & 1729.00 & 3 & 2700.72 & 15.0 \\
\hline 1543 & 0.5754 & 0.3953 & 2.425 & 1663.77 & 4 & 3069.41 & 17.5 \\
\hline 1443 & 0.5359 & 0.3553 & 2.578 & 1318.88 & 4.5 & 4879.36 & 29.6 \\
\hline 1339 & 0.4787 & 0.3286 & 2.583 & 1397.76 & 5 & 4053.22 & 24.6 \\
\hline 1271 & 0.4252 & 0.2922 & 2.690 & 1514.54 & 5.5 & 5032.84 & 31.9 \\
\hline 1188 & 0.3661 & 0.2666 & 2.644 & 1687.91 & 6 & 4306.65 & 26.8 \\
\hline 1134 & 0.321 & 0.2386 & 2.695 & 1923.22 & 6.5 & 4872.13 & 30.9 \\
\hline 1069 & 0.2902 & 0.224 & 2.643 & 2025.55 & 7.5 & 4553.93 & 28.3 \\
\hline 1027 & 0.2572 & 0.2065 & 2.584 & & 8 & & \\
\hline 976 & 0.2436 & 0.2003 & 2.520 & & 8.5 & & \\
\hline & & & \multicolumn{2}{|c|}{$\begin{array}{c}\langle d\rangle 1657.58 \\
\exp 1689 \mathrm{~nm}\end{array}$} & & & \\
\hline
\end{tabular}

Table III

Calculated optical properties by Swanepoel method for CdTe thin films (sample 21)

\begin{tabular}{|l|c|c|c|c|c|c|c|}
\hline$\lambda, \mathbf{n m}$ & $\mathbf{T}_{\mathbf{M}}$ & $\mathbf{T}_{\mathbf{m}}$ & $\mathbf{n}$ & $\mathbf{d}_{\mathbf{1}}, \mathbf{n m}$ & $\mathbf{m}$ & $\boldsymbol{\alpha}, \mathbf{c m}^{-\mathbf{1}}$ & $\boldsymbol{\sigma}_{\mathbf{p p t}}, \mathbf{1 0}^{\mathbf{1 1}}$ \\
\hline 2498 & 0.9441 & 0.5529 & 2.382 & & & & \\
\hline 2181 & 0.9362 & 0.5474 & 2.391 & & & & \\
\hline 1935 & 0.914 & 0.5506 & 2.353 & 1403.159 & 3 & 64.44 & 2.85 \\
\hline 1752 & 0.8929 & 0.5377 & 2.372 & 1442.819 & 4 & 511.03 & 2.53 \\
\hline 1596 & 0.8624 & 0.5302 & 2.358 & 1414.053 & 4.5 & 455.21 & 6.75 \\
\hline 1474 & 0.8305 & 0.5024 & 2.420 & 1437.777 & 5 & 1185.00 & 5.06 \\
\hline 1363 & 0.7756 & 0.4869 & 2.397 & 1316.820 & 5.5 & 896.46 & 11.6 \\
\hline 1277 & 0.726 & 0.4498 & 2.479 & 1467.810 & 6 & 1981.87 & 9.55 \\
\hline 1192 & 0.66 & 0.4287 & 2.451 & 1481.673 & 6.5 & 1656.57 & 106 \\
\hline 1129 & 0.5966 & 0.3158 & 3.043 & & 7.5 & 1480.10 & 5.8 \\
\hline 1064 & 0.541 & 0.3742 & 2.457 & 1473.072 & 8 & 1005.82 & 15 \\
\hline 1016 & 0.4881 & 0.3383 & 2.539 & 1547.714 & 8.5 & 2523.31 & 18 \\
\hline 965 & 0.4509 & 0.3252 & 2.490 & 1444.584 & 9.5 & 3076.79 & 22.6 \\
\hline 928 & 0.4095 & 0.2977 & 2.548 & 1422.981 & 10.5 & 3766.45 & 19.7 \\
\hline 889 & 0.3759 & 0.2835 & 2.500 & 1403.159 & 11.5 & 3346.23 & \\
\hline & & & $\boldsymbol{e x p} \mathbf{1 4 8 5} \mathbf{n m}$ & & & & \\
\hline
\end{tabular}


Table IV

Calculated optical properties by Swanepoel method for CdS/CdTe heterojunction (sample 24)

\begin{tabular}{|c|c|c|c|c|c|c|c|}
\hline $\boldsymbol{\lambda} \mathbf{n m}$ & $\mathbf{T}_{\mathbf{M}}$ & $\mathbf{T}_{\mathbf{m}}$ & $\mathbf{n}$ & $\mathbf{d}_{\mathbf{1}}, \mathbf{n m}$ & $\mathbf{m}$ & $\boldsymbol{\alpha}, \mathbf{c m}^{\mathbf{- 1}}$ & $\boldsymbol{\sigma}_{\mathbf{o p t}}, \mathbf{1 0}^{\mathbf{1 1}}$ \\
\hline 1804 & 0.3662 & 0.2589 & 2.745 & & & & \\
\hline 1611 & 0.3907 & 0.2698 & 2.758 & & & & \\
\hline 1434 & 0.4132 & 0.2783 & 2.781 & 1196.811 & 3.5 & 5683.348 & 37.2 \\
\hline 1304 & 0.4402 & 0.2983 & 2.699 & 1396.410 & 4 & 3771.711 & 24 \\
\hline 1188 & 0.4758 & 0.3073 & 2.763 & 1293.906 & 4.5 & 4733.311 & 30.8 \\
\hline 1102 & 0.5022 & 0.3264 & 2.692 & 1341.083 & 5 & 3214.134 & 20.4 \\
\hline 1023 & 0.5409 & 0.3457 & 2.666 & 1781.445 & 6 & 2375.072 & 14.9 \\
\hline 961 & 0.6244 & 0.3783 & 2.665 & 1516.782 & 6.5 & 2219.331 & 13.9 \\
\hline & & & \multicolumn{2}{|c|}{ (d) $\mathbf{1 4 2 1 . 0 7 1}$} & & & \\
\hline
\end{tabular}

Table V

Calculated optical properties by Swanepoel method for CdTe thin films (sample 24)

\begin{tabular}{|c|c|c|c|c|c|c|c|}
\hline$\lambda, \mathbf{n m}$ & $\mathbf{T}_{\mathbf{M}}$ & $\mathbf{T}_{\mathbf{m}}$ & $\mathbf{n}$ & $\mathbf{d}_{1}, \mathbf{n m}$ & $\mathbf{m}$ & $\alpha, \mathrm{cm}^{-1}$ & $\sigma_{\text {opt }}, 10^{11}$ \\
\hline 2477 & 0.885 & 0.5265 & 2.402 & & & & \\
\hline 2066 & 0.8812 & 0.5172 & 2.432 & & & & \\
\hline 1782 & 0.8764 & 0.5191 & 2.419 & 1290.680 & 2.5 & 571.4192 & 3,25 \\
\hline 1566 & 0.8664 & 0.5077 & 2.449 & 1293.241 & 3 & 1040.131 & 5,99 \\
\hline 1397 & 0.8549 & 0.5069 & 2.436 & 1292.578 & 3.5 & 724.5566 & 4,15 \\
\hline 1268 & 0.8444 & 0.4914 & 2.484 & 1265.469 & 4 & 1369.256 & 8 \\
\hline 1159 & 0.826 & 0.4907 & 2.461 & 1319.135 & 4.5 & 808.1503 & 4,68 \\
\hline 1073 & 0.8111 & 0.4724 & 2.516 & 1294.507 & 5.5 & 1637.885 & 9,7 \\
\hline 998 & 0.7767 & 0.4691 & 2.478 & 1391.304 & 6 & 972.2801 & 5,67 \\
\hline 939 & 0.7573 & 0.4466 & 2.550 & 1350.514 & 7 & 2085.314 & $12,5 \mathrm{E}$ \\
\hline 888 & 0.6826 & 0.4379 & 2.452 & 1792.857 & 8 & 947.8748 & 5,47 \\
\hline 850 & 0.6309 & 0.4286 & 2.380 & & 9 & & \\
\hline & & & \multicolumn{2}{|c|}{$\begin{array}{c}\text { (d) } 1365.59 \\
\exp 1215 \mathrm{~nm}\end{array}$} & & & \\
\hline
\end{tabular}




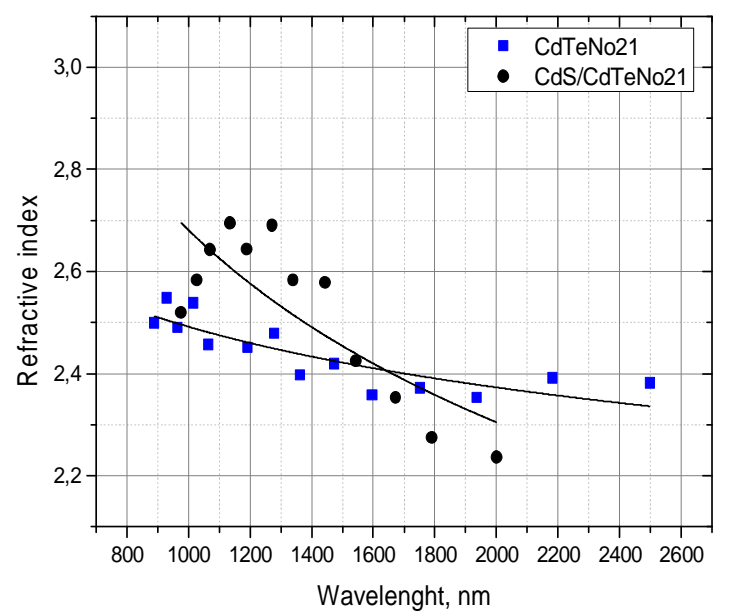

Fig. 4. Refractive index versus wavelength of $\mathrm{CdTe}$ thin film and heterojunction of $\mathrm{CdS} / \mathrm{CdTe}$ (sample 21).

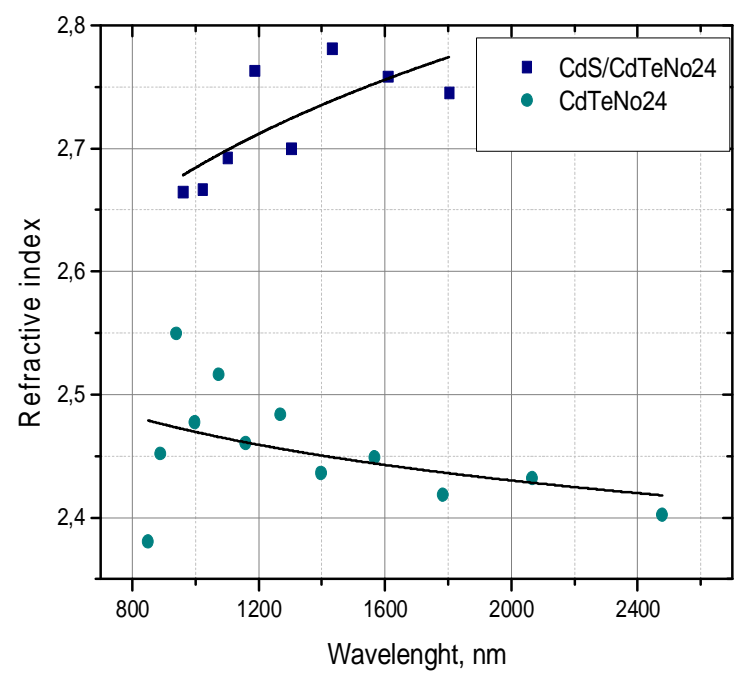

Fig. 5. Refractive index versus wavelength of CdTe thin film and heterojunction of $\mathrm{CdS} / \mathrm{CdTe}$ (sample 24).

$$
m=\left(\frac{\lambda_{2}}{\lambda_{1}-\lambda_{2}}\right) \text {, }
$$

where $\lambda_{1}$ and $\lambda_{2}$ are the wavelengths of two adjacent transmission maxima $\left(\lambda_{1}>\lambda_{2}\right)$.

For a region where is a strong absorption of light, the refractive index is determined as follows:

where

$$
\alpha=\frac{1}{d} \ln \frac{(n-1)^{3}\left(n-s^{2}\right)}{E_{m}-\left(c_{m}^{2}-\left(n^{2}-1\right)^{3}\left(n^{2}-s^{4}\right)^{0 \cdot 5}\right.}
$$

$$
E_{m}=\left(\frac{m^{2} s}{T_{m}}\right)-\left(n^{2}-1\right)\left(n^{2}-s^{2}\right)
$$

For heterojunction $\mathrm{CdS} / \mathrm{CdTe}$ takes place a significant increase in the absorption coefficient of light several times, primarily in the short-wave region of the spectrum (Fig. 6-7). This is due to the fact that the thin layer of CdS thanks to the large band gap $(2.42 \mathrm{eV})$ plays the role of an «absorption window» for absorbing light.

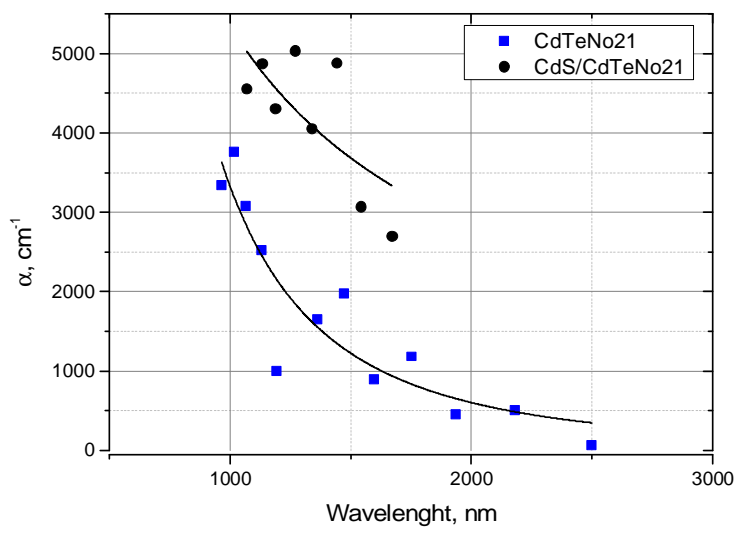

Fig. 6. Absorption coefficient versus wavelength of CdTe thin film and heterojunction of $\mathrm{CdS} / \mathrm{CdTe}$ (sample 21).

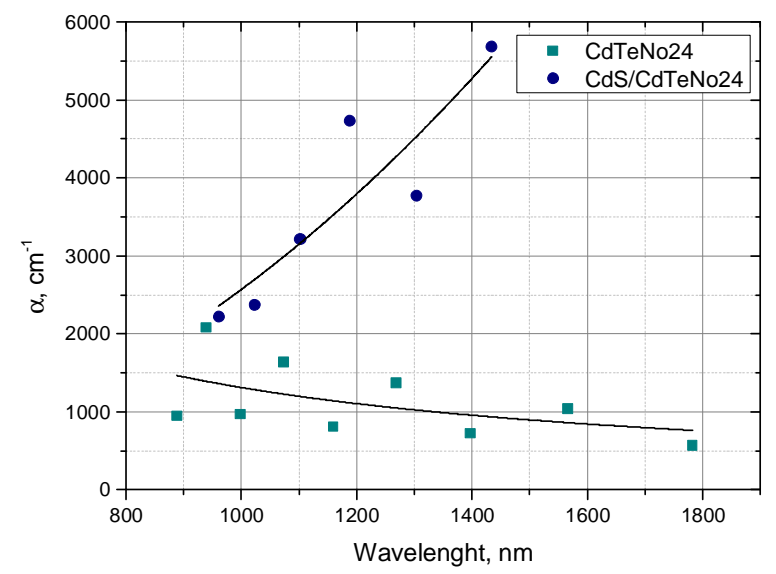

Fig. 7. Absorption coefficient versus wavelength of CdTe thin film and heterojunction of $\mathrm{CdS} / \mathrm{CdTe}$ (sample 21).

The photons absorbed in the window layer do not contribute to the photocurrent, as recombination is very likely to occur, resulting in scattering of light. Therefore, absorption in the CdS layer is a source of significant loss.

For samples 21 and 24, a significant difference in absorption coefficients is observed for the corresponding wavelengths. It can be noted that the absorption coefficient for thin films of CdTe acquires larger values than for the $\mathrm{CdS} / \mathrm{CdTe}$ heterojunction at the corresponding wavelengths for both specimens.

\section{Conclusions}

1. CdS/CdTe heterojunction on glass substrates are deposited by the method of open evaporation in a vacuum for various technological factors, including different thicknesses.

2. An analysis of the optical properties of thin films of CdTe was carried out and their change after the addition of an "absorption window" of $\mathrm{CdS}$ was investigated. 
3. It was found that the thin layer of $\mathrm{CdS}$ significantly increases the absorption properties of the film.

4. The thickness of the film is theoretically calculated and the results obtained coincide with the experimental studies of the profilometer.

5. It is shown that CdS / CdTe heterojunction due to their high absorption capacity have the prospect of using as photovoltaic light converters.

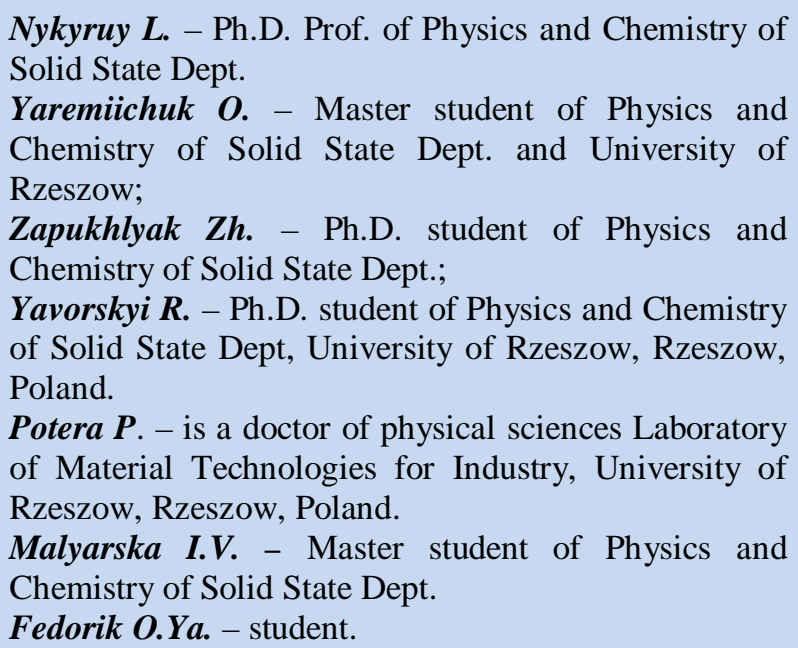

Nykyruy L. - Ph.D. Prof. of Physics and Chemistry of Solid State Dept.

Yaremiichuk O. - Master student of Physics and Chemistry of Solid State Dept. and University of Rzeszow;

Zapukhlyak Zh. - Ph.D. student of Physics and Chemistry of Solid State Dept.;

Yavorskyi R. - Ph.D. student of Physics and Chemistry of Solid State Dept, University of Rzeszow, Rzeszow, Poland.

Potera $\boldsymbol{P}$. - is a doctor of physical sciences Laboratory of Material Technologies for Industry, University of Rzeszow, Rzeszow, Poland.

Malyarska I.V. - Master student of Physics and Chemistry of Solid State Dept.

Fedorik O.Ya. - student.

[1]. M.A. Green, K. Emery, Y. Hishikawa, W. Warta, E.D. Dunlop, Solar cell efficiency tables (version 41), Prog. Photovolt. Res. Appl. 21 (2013) 1.

[2]. R. Swami, Solar cell, Int. J. Sci. Res. Publ. 2 (2012) 1.

[3]. L. Kosyachenko, T. Toyama, Current-voltage characteristics and quantum efficiency spectra of efficient thinfilm CdS/CdTe solar cells, Sol. Energy Mater. Sol. Cells 120 (2014) 512.

[4]. L. Zhi, F. Lianghuan, Z. Guanggen, L. Wei, Z. Jingquan, W. Lili, W. Wenwu, Influence of CuxS back contact on CdTe thin film solar cells, J. Semicond. 34 (2013) 014008.

[5]. H. Kim, K. Cha, V.M. Fthenakis, P. Sinha, T. Hur, Sol. Energy 103, 78 (2014).

[6]. L. Kranz, S. Buecheler, A.N. Tiwari, Sol. Energ. Mat. Sol. C. 119, 278 (2013).

[7]. M.A. Green, K. Emery, Y. Hishikawa, W. Warta, Progr. Photovolt.: Res. Appl. 21,827 (2013).

[8]. Britt and Ferekides, 1993; Ohyama et al., 1997

[9]. http://www.firstsolar.com/, dost. z dn. 17/06/2013.

[10]. S. Girish Kumar, K.S.R. Koteswara Rao, Energ. Environ. Sci. 7, 45 (2014).

[11]. A.Romeo, M. Arnold, D.L. Batzner, H. Zogg, A.N. Tiwari, Proc. Conf. " PV in Europe from PV Technology to Energy Solutions". Rome, 377 (2002).

[12]. V.Valdna, J. Hiie, Pros. 17th European Photovoltaic Solar Energy Conference. Munich, 1233 (2001).

[13]. J. Perrenoud, S. Buecheler, A. N. Tiwari, „Flexible CdTe solar cells with high photovoltaic conversion efficiency", 34th IEEE Photovoltaic Specialists Conference PVSC, Philadelphia, PA, USA, 695-699, (2009).

[14]. W. L. Rance, J. M. Burst, M. O. Reese, D. M. Meysing, C. A. Wolden, T. A. Gessert, S. Garner, X. Li, P. Cimo, C. Kosik-Williams, T. M. Barne, „Flexible CdTe superstrate solar cells on flexible glass”, IEEE 39th Photovoltaic Specialists Conference, Tampa, FL, USA, (2013).

[15]. R.S. Yavorskyi, Z.R. Zapukhlyak, Ya.S. Yavorskyi, L.I. Nykyruy. Vapor Phase Condensation for Photovoltaic CdTe Films. Physics and Chemistry of Solid State V. 18, № 4 (2017) P. 410-416. DOI: $10.15330 /$ pcss.18.4.416.

[16]. J. C. Manifacier, J. Gasiot, and J. P. Fillard, J. Phys. E: Sci. Instrum. 9, 1002 (1976).

[17]. R. Swanepoel, J. Phys. E, Sci. Instrum. 16, 1214 (1983).

[18]. R. Swanepoel, J. Phys. E, Sci. Instrum. 17, 896 (1984)

[19]. F. Alvarez, N. Lalla, A. Lamagana, „Thin film CdS/CdTe solar cells prepared by electrodeposition using low cost material", 26th IEEE Photovoltaic Specialists Conference, 459-462, (1997).

[20]. L.A. Kosyachenko, A.I. Savchuk, E.V. Grushko, Dependence of efficiency of thin-film CdS/CdTe solar cell on parameters of absorber layer and barrier structure, Thin Solid Films 517 (2009) 2386.

[21]. H.A. Mohamed, Influence of the optical and recombination losses on the efficiency of CdS/CdTe solar cell at ultrathin absorber layer, Can. J. Phys. 92 (2014) 1350.

[22]. L.A. Kosyachenko, E.V. Grushko, V.V. Motushchuk, Recombination losses in thin-film CdS/CdTe photovoltaic devices, Sol. Energy Mater. Sol. Cells 90 (2006) 2201.

[23]. V.V. Brus, On quantum efficiency of nonideal solar cells, Sol. Energy 86 (2012) 786.

[24]. H.A. Mohamed, Dependence of efficiency of thin-film CdS/CdTe solar cell on optical and recombination losses, J. Appl. Phys. 113 (2013) 093105.

[25]. G.Wisz, I.Virt, P.Sagan, P.Potera, R.Yavorskyi. Structural, optical and electrical properties of Zinc Oxide layers produced by pulsed laser deposition method // Nanoscale Research Letters. - 2017. - 12: 253. DOI: 10.1186/s11671-017-2033-9

[26]. Punitha K. et al 2014.

[27]. Yavorskyi, R., Nykyruy, L., Wisz, G. et al. Appl Nanosci (2018). https://doi.org/10.1007/s13204-018-0872-z. 
[28]. Moshfegh A et al 2005; Punitha K et al 2014.

[29]. Swanepoel R 1983; Shaaban E 2012.

[30]. Swanepoel R: Determination of the Thickness and Optical Constants of Amorphous Silicon. J. Phys. E 1983, 16: 1214-1224. 10.1088/0022-3735/16/12/023.

[31]. R. E. Treharne, A. Seymour-Pierce, K. Durose, K. Hutchings, S. Roncallo, D. Lane, Optical design and fabrication of fully sputtered CdTe/CdS solar cells, J. Phys: Conf. Ser. 286, 012038, (2011).

[32]. Lisco, F., Kaminski, P. M., Abbas, A., Bowers, J. W., Claudio, G., Losurdo, M., \& Walls, J. M. (2015). High rate deposition of thin film cadmium sulphide by pulsed direct current magnetron sputtering. Thin Solid Films, 574, 43-51.

\title{
Л.І. Никируй${ }^{1}$ О.В. Яремійчук ${ }^{1,2}$, Ж.Р. Запухляк ${ }^{1,2}$, Р.С. Яворський ${ }^{1,2}$, П. Потера ${ }^{2}$, І.В. Малярська ${ }^{1}$, О.Я. Федорик ${ }^{1}$ \\ Оптичні властивості гетероструктури CdS / CdTe, отримані методом фізичного осадження з парової фази
}

\author{
${ }^{1}$ ДВНЗ «Прикарпатський начіональний університет імені Василя Стефаника», вул. Шевченка, 57, \\ 76018, м. Івано-Франківськ, Україна, E-mail: roctyslaw@gmail.com \\ ${ }^{2}$ Жешувський університет, вул. Рейтана 16С, 35-959 Жешув, Польща
}

У статті наведено дослідження оптичних властивостей тонкого шару сульфіду кадмію в плівках телуриду кадмію. Тонкі плівки СdTе були отримані методом відкритого випаровування у вакуумі, використовуючи різні технологічні фактори, зокрема, різну товщину (різний час осадження $\tau$ ) на скляних підкладах. Після осадження оптичні властивості аналізували методом Swanepoel, використовуючи спектри пропускання. Наступний тонкий шар $\mathrm{CdS}$ осаджувався методом термічного випаровування на тонких плівках CdTe. Досліджено зміну оптичних властивостей гетероструктури CdS/CdTe у порівнянні 3 тонкими плівками CdTe. Використовуючи метод Swanepoel, розраховано основні оптичні константи, такі як показник заломлення, коефіцієнт поглинання та оптична провідність. За допомогою цього методу отримано товщину тонкої плівки та порівняно іiі з експериментальними значеннями, отриманих за допомогою профілометра. 